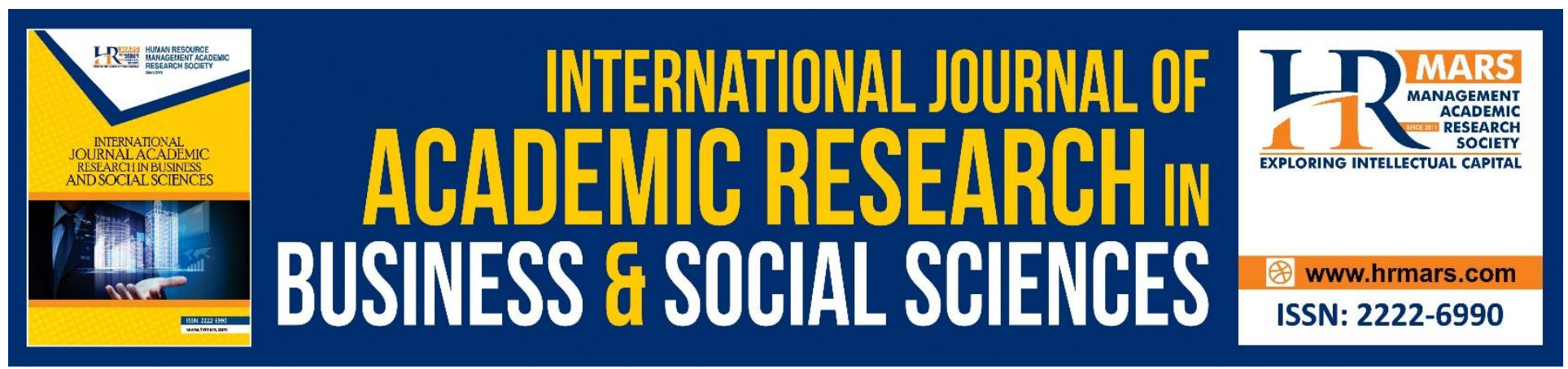

\title{
An Analysis of the Hiyal Syariyyah Concept Pertaining to Deferred Products in Malaysia
}

Sumayyah Abdul Aziz \& Nadhirah Nordin

To Link this Article: http://dx.doi.org/10.6007/IJARBSS/v9-i6/5945

DOI: $10.6007 /$ IJARBSS/v9-i6/5945

Received: 10 April 2019, Revised: 25 May 2019, Accepted: 05 June 2019

Published Online: 28 June 2019

In-Text Citation: (Aziz \& Nadhirah Nordin, 2019)

To Cite this Article: Aziz, S. A., \& Nadhirah Nordin. (2019). An Analysis of the Hiyal Syariyyah Concept Pertaining to Deferred Products in Malaysia. International Journal of Academic Research in Business and Social Sciences, 9(6), 259-270.

\section{Copyright: (C) 2019 The Author(s)}

Published by Human Resource Management Academic Research Society (www.hrmars.com)

This article is published under the Creative Commons Attribution (CC BY 4.0) license. Anyone may reproduce, distribute, translate and create derivative works of this article (for both commercial and non-commercial purposes), subject to full attribution to the original publication and authors. The full terms of this license may be seen at: http://creativecommons.org/licences/by/4.0/legalcode

Vol. 9, No. 6, 2019, Pg. 259 - 270

Full Terms \& Conditions of access and use can be found at http://hrmars.com/index.php/pages/detail/publication-ethics 


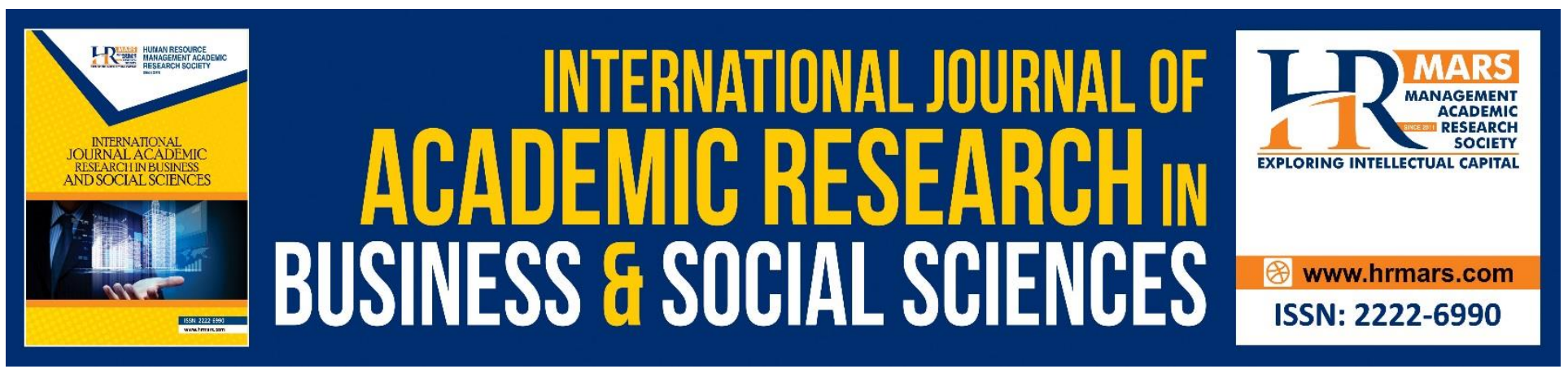

\title{
An Analysis of the Hiyal Syariyyah Concept Pertaining to Deferred Products in Malaysia
}

\author{
Sumayyah Abdul Aziz \& Nadhirah Nordin \\ Faculty of Islamic Contemporary Studies, Universiti Sultan Zainal Abidin, Gong Badak Campus, Kuala \\ Nerus, Terengganu, Malaysia.
}

\begin{abstract}
Deferred products are classic in nature and should be adapted into the contemporary Islamic financial system. Thus, there arises a need to determine how far the importance of deferred products are implemented according to the contemporary circumstances in Malaysia. This is to ensure that deferred products, as in controversial products such as inah, play a role in the syariah context and at the same time be competitive in the banking industry and Islamic finance. This study analysed deferred products as a form of a conventional frame from a hilah aspect and discussions related to theories on hiyal that have an effect on deferred products, which fulfil current and local needs as well as comply with the maqașid al-shariah framework in Islamic finance. This qualitative study obtained data through a document analysis. The findings showed that the use of hiyal in deferred products should follow a streamed-lined or uniform hiyal according to maqașid al-shariah.
\end{abstract}

Keywords: Hiyal, Maqașid Al-Shariah, Deferred Products, Islamic Financial System

\section{Introduction}

According to Aziz (2016 : 247), deferred products according to Malaysias Islamic banking system contains two elements, namely products based on debt and products based on sales and purchase. Deferred products according to the Malaysian banking system applies principles such as Tawarruq, Murabahah, BBA, Inah, Salam and Istisna. Products that are structured based on a deferred agreement ( $a k a d$ ) have fulfilled the outlined tenets (rukun) and agreement ( $a k a d$ ); moreover, their status is still involved in continuous discussions and debates (Aziz, 2017). This involves deferred products that are structured based on current needs. For example, akad inah, which is permitted, considers a banking situation that has not matured at that time and it only permits products that are difficult to be structured, such as inah, that has proved the practice of darürah in its banking products. Hence, deferred products in Malaysia are dominated either from aspects of profit or customer demand. (The Council in The Regional Shariah Scholars Dialogue, 2006) 
The inclusion of deferred products in Islamic banking products is closely related with the use of hilah or makhraj according to differences in meaning and application of Islamic law. According to Abu Bakar et al., (2009 : 690) the differences in view and acceptance between the fuqaha and Ulama Ușul pertaining to the application of hilah is related to the last maqașid of a particular law. Following this, the controversy regarding deferred products in Islamic banking is due to the method of differentiating socioeconomic importance and shariah principles. This element is very important because the Maqașid for safeguarding property comprises two aspects. The differences in evaluating a ḍaūrah situation in maqașid al-shariah has an implication on producing a product that does not fulfil the actual criteria of syarak. (Wajdi, 2008 ; Chapra, 2008)

This article discusses the hiyal theory pertaining to deferred products, fiqh and contemporary ijtihad. Next, this article discusses the application of hiyal theory in contemporary needs in order to determine the current Islamic law as well as a depiction of Islamic financial practices in Malaysia.

\section{The Hiyal Theory According to the Fiqh Perspective}

Hilah, from a language aspect, means all forms of relationships or connections that achieve its aim in a covert or concealed manner (Ibn Hajar, 2003). The word hiyal is the singular for hilah, which means to achieve through a stratagem or a form of trickery (al-Wasit, 2:209) ${ }^{1}$. However, hilah is not presumed to be an alternative to evade Islamic law. There are several meanings of al-hilah, which means an effort to change or avoid from the fate of the original law to another aspect of law without being bound by the demands of syarak. (Mahrus, 2013)

According to fuqaha terminology, hilah means tahayyul, which retrospectively indicates that as if it is a practice prohibited by syarak or an action that is disallowed by syarak but purportedly presumed to be accepted by syarak. This is done with the aim of avoiding responsibility or blame when something prohibited is carried out. Therefore, tahayyul or hilah in Shariah according to this context is related to a practice whose prohibition is in the form of syarie, which is a prohibition by Allah SWT. However, doing something permitted by syarak and using different methods or providing a means for doing it is not presumed to be a form of manipulation or tahayyul because the action is known as management or eagerness (hirș) or being pious (warak).

Hiyal has a long history of debates and arguments among the fuqaha. Generally, the debate started due to differences in methodology among the different fiqh sects from its istidlal aspect. The Hiyal Theory was discussed in-depth by the Malikiyah, Hanbali and Hanafiah fuqaha. Scholars from the Hanbali sect, such as Ibn Taimiyyah and his student, Ibn al-Qayyim, had built a case against hiyal based on three different main points. First, they looked into the objective of legitimising the law according to syariat or maqașid al-shariah. Second, they looked into the role of intention and third, they examined classic discussions by the Ulama Usul, which was about the ușuli method that blocks the means or sadd al-dharai. All three components above represent different arguments about hiyal. However, the Hanbali sect used it as an argument for formulating their law about hiyal.

\footnotetext{
1 Mu'jam al-Wasit, 2:209, entri: hiyal.
} 
Basically, the two components of the argument, namely objective of the shariah and intention, was used to show that the hiyal theory basically contradicts Islamic law; whereas the sadd al-dharai argument indicates incompatibility between hiyal and maqașid al-kulliyah (Ibn al-Qayyim, 1996 ; Imran Muhammed Ismail, 2010 ; Frank E. Vogel \& Samuel L. Hayes lii, 1998). However, Imam Shafii held an opposing view because for him, intention has no effect on agreement ( $a k a d)$. Nevertheless, he stated that there was no element of early preparation when initiating the agreement ( $a k a d)$ process in order to obtain the reason for transgressing maqașid al-shariah.

There are general and specific definitions of hiyal that have been used by fiqh scholars. The general interpretation covers both forms of hiyal, which is hiyal that is prohibited and hiyal that is permitted. Whereas, the specific interpretation is more towards hilah that is permitted or limited to hilah that is prohibited. Generally, the Ulama have divided hiyal into hiyal that is prohibited if the way to achieve something totally unacceptable contradicts syarak, either by negating syarak law or changing it to another law, such as abstaining from what is mandatory and permitting what is prohibited as well as impair qawaid al-Shariah. The existence of hiyal in this category was agreed upon by ulama from all the sects (mazhab). (Fairooz, 2011)

\section{The Hiyal Theory in Contemporary ljtihad}

The hiyal theory should be investigated further so that hilah is not the only mechanism for building the current ijtihad. This will ensure that those who receive hilah as one of the mechanisms for implementing the law need to apply hilah with caution. Since hilah is a deep-seated motive, the action would be evaluated according to the intention. Hence, the aspect of laying importance on motive or providing a means in any recognition of law substantiates the statement that Islam emphasises more on substance rather than the external framework. In other words, the essence surpasses the framework. (Abu Bakar et al., 2009)

A review for the need of hilah in the current ijtihad looks into the methodology of two contradicting sects from the aspect of the instinbat law framework, which refers to the Hanbali Sect like Ibn al-Qayyim and the Hanafi Sect like al-Sarakahsi (1999 : 93) and al-Shaybani (1999 : 90). Imam Abu Hanifahs methodology was different to that of Ibn Qayyim, as it considered the maqașid of substantive law, especially the part of dividing usury (riba) that considers the factor of intent of hilah being implemented and the implication on the final consequence of the action accruing from the act based on hilah.

The ulama who were against the use of hilah argued that hilah could cause the loss of shariahs essence. Moreover, it is seen to belittle the sustainability as well as dignity of maqașid al-shariah. Hence, the difference between the two opinions is more substantial, whereby basically the use if hilah is still subject to the laws of figh that is closely related to laws pertaining to haram (prohibited), halal (permitted), mandub, makruh and mubah. As stated by al-Shatibi (2003: 328) this situation is suitable with the current context, which is substantiated with the view that permits hilah and not to destroy the spirit of syariah so that it is not included in the category of hilah that is prohibited or 
INTERNATIONAL JOURNAL OF ACADEMIC RESEARCH IN BUSINESS AND SOCIAL SCIENCES Vol. 9, No. 6, June, 2019, E-ISSN: 2222-6990 @ 2019 HRMARS

despised. Therefore, the context of hilah from its structural aspect is evident from the justification of its element of substance that surpasses the element of its framework. This situation ensures that the use of hilah is not solely dependent on the technical term so much so that it entraps when used, which needs close examination based on various contexts and different implication of the law through certain cases (juziy).

\section{The Hiyal Theory in Deferred Products}

Products based on hilah, such as Bay Inah, are consumed in order to avoid being involved in ribawi products. There are apprehensions concerning disputes about Islamic financial products as to whether hilah can overcome the legislative constraints and limitations on innovative products or vice versa. Hence, classic discussions about the hiyal theory should be re-analysed in order to determine whether the theory and its practice has failed in achieving the aims of hilah as an alternative to usury (riba) or has it succeeded in becoming the makharij to usury (riba). (Muhammed Imran Ismail, 2010)

Criticisms from Islamic economists had characterised Islamic financial products to be solely in the form of a framework. This was outlined by Habib Ahmed when he divided the formation of Islamic banking products conceptually into three forms. First was the pseudo-Islamic product, which is a product that uses hilah as an alternative. Pseudo-Islamic products fulfil the needs and tenets of sales and purchase but do not possess the element of maqașid, which aims to serve social needs. Second, these products should be Shariah-compliant and Shariah-based (Habib Ahmed, 2011 ; Habib Ahmed, 2011). The problem arises when the product building process does not aim to fulfil criteria for Shariah-based products, which inadvertently accomplishes the social and maqașid goal or essence.

Saleh (1991 : 123) asserts that the internal challenge in Islamic banking is the way of interacting using hiyal in order to cancel out the prohibitions of usury (riba) and gharar. Various allegations and arguments have stated that Islam prohibits usury (riba) but by using another term as an alternative, namely, hiyal or hiyal shariyyah (legal stratagems), it helps the creditor to obtain higher returns compared to current interests. El-Gamal (2006: 82) criticised this approach by saying that hiyal shariyyah is a cunning approach in reality because it provides financing but sells and buys with a profit margin. He stressed that by solely focusing on the legal context while neglecting the ethical implications, prohibiting usury ( $r i b a)$ could lead to an injunction on shariah as well as neglecting the meaning of shariah. (Mahmoud \& Elgamal, 2006)

The form of finances in the profit-sharing element, including hilah, for organising the profit as a percentage of the initial capital is not something new. According to Abraham Udovitch (1981) this practice has become a form of trade financing during the mid-Mediterranean era referred to as "bankers without banks". Much of Udovitchs analysis is based on his study of the compendium of Hanafi Jurisprudence al-Mabsut by al-Sarakhsi, which listed numerous legal stratagems or ruses that are not dislike those utilized today in Islamic finance to replicate conventional financial practices. (Elgamal, 2006 ; Udovitch, 1981)

Based on studies, this matter has continued in Islamic banking practices until now. Ismail (2010:2) stated the legal stratagems or also called hiyal, have been widely practiced in Islamic 
banking and financial industry, and the voice that has protested against this practice has grown in volume. The apprehension that was voiced was concerning the industrys habit in giving default templates as the new instruments design for future Islamic financial products. In 1998, Vogel was of the view that there was a need to re-open debates by classic ulama in order to resolve the dispute pertaining to Islamic financial products in deciding whether hilah (artifice) could overcome legal constraints and limitations on product innovation or inadvertently it has failed in achieving the aim of hilah as a way-out from usury (riba). (Vogel, 1998)

Such a practice has not been accepted by most Islamic scholars. Moreover, majority of them have voiced their disagreement to this practice. Among them are Ibn Batta (1988:41), Ibn Qudamah (2004: 834) and Ibn al-Qayyim (1996: 87). Besides that, there is a need to thoroughly examine their writings that have been alleged to use hilah widely to determine whether they had actually used it. Abu Yusuf and al-Shaybani (1999: 90), are two writers who have extensively written on differing principles about Hiyal. Hiyal does exist in Islam and in some instances is permitted but Islam has principles that curtail or lessen its use rather than encourage its practice.

In relation to the discussions above, criticisms in the context of deferred products appears when most banking products are hilah-based.

As stated by Munawar lqbal (2013 : 17):-

"...the way this instrument is being practised by banks is very different. It appears to be simply a "devious artifice" (hilah) to get around the prohibition of interest through an intermediate process, the end result being what was prohibited... The few scholars who have allowed tawarruq require the banks to actually buy and at least take constructive possession of the commodities, and then sell them."

According to Munawar, contemporary banking instruments are seen as a hilah in order to avoid the prohibition of usury ( $r i b a$ ) from the immediate process produced by usury (riba) in the form of interest. A small number of scholars who allow tawarruq have requested that banks actually buy the assets or at least take the right of possession constructively from the commodity and then re-sell it.

The problem of hilah related to products and financial instruments is not only limited solely to the question of fiqhi and ikhtilaf, but rather according to in-depth studies on credit products based on hilah through the fractional reserve system offered by Islamic banks. For example, a buyback (inah) transaction encourages economic instability and inflationary pressure because the contracts framework is based on the overall assets of the supply unit according to the rate of monetary supply. Hence, according to the analysis, there is a correlation and direct relationship between the products based on hilah and inflation. (Yaakob \& Khalid, 2014)

This is similar to the inverse relationship between hilah and currency value (buying power). It could be concluded based on this finding that Islamic banking as the financier involved deeply in supplying (bay' al-inah) based on the element of hilah through the fractional reserve system, cannot 
provide a solution for the financial and economic problems that occur, especially due to inflationary pressure (Firdaus Mohammad Hatta et al., 2014). This situation explains the product issue based on hilah although hilah shariyyah is not limited in fiqh matters, rather it can create credit debts that produce an Islamic financial and economic bubble. (Hassan, 2015)

A new approach in personal financing with improvements to the current contract is needed. This is because problems such as hilah, which have been agreed between the client and the bank concerning bay' al-înah products, could jeopardise shariah-complaint contracts. Stipulations regarding conditions for goods is that it must be sold back to the original seller (bank) and the pact that exist before the akad with the bank has stipulated prior conditions that two transactions should occur.

It is feared that this arrangement would lead to hilah ribawiyyah, which would make the contract illegal according to law. Therefore, among the mechanisms that can help avoid hilah from occurring in the contract would be to use three parties in the al-tawarruq contract, in which the first party is the client or lessee, the second party is the bank and the third party is the leasing institution or receiver of the leased goods. (Ahmad, 2011)

\section{The Aspect of Forming Hilah in Deferred Products}

Actually, the element of hilah in Islamic products and finance is rather complex because the parties involved are more focused on dealing with the literal aspect of nas shariah and also the issues of legal ethics (Mawil Izzi Dien, 2008). The permissibility context allowed by Imam Hanafi refers to whatever that is given to the Ummah and prevents them from transgressing Shariah law (Khașaf, 1968). In the context of a definition, riba al-fadll is more complex because it involves socio-economical aspects as a preventive measure; hence, it must ensure that the product formed does not contain elements of riba al-faḍl. 


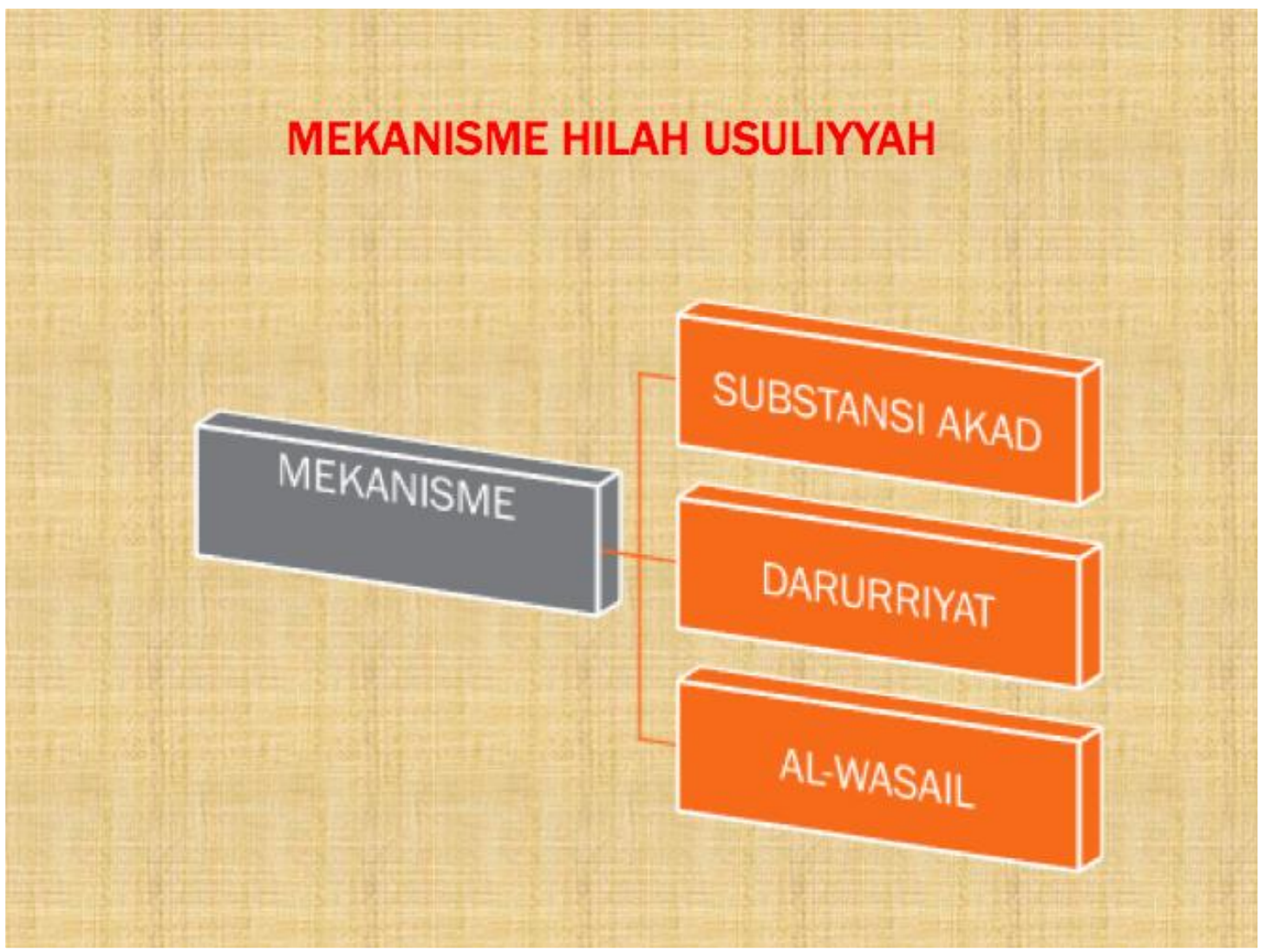

Based on the diagram above, hiyal in deferred products is temporarily permissible in order to achieve maqașid așliyyah, maqașid kulliyyah and maqașid ammah related to the safeguarding of property, which is from the aspect of its existence (janib al-wujud) and avoidance from destruction (janib al-adam). Thus, from this perspective, Hiyal is usually planned to maintain the existence of the property and develop it until it is beneficial for all segments of society. Hence, if hiyal is not implemented, a bigger disaster would occur in the form of difficulties and destruction to the commercial (muamalat) or financial systems that are operating. Hiyal during the time of daruriyyat, is given priority compared to hiyal in the maqașid tabiyyah and juziyyah positions (Hashim et al., 2015). Thus, the hiyal that is permitted is hiyal that has become mukammil and is related (wasilah) to the achievement of maqașid for commerce. Therefore, determining the forms of hilah in deferred products comprises several elements of law on maqasid and wasail.

Maqasid and wasail are important elements in the current context and place for the al-darurah concept in the al-maqasid framework for deferred products in Malaysia. Al-wasail is a dynamic factor in deciding the need and implementation of a product based on current factors. Pre-intent (maqsud al-mutaaqidayn) and post-outcome (maalat al-afal) are also deciding factors of current needs because this principle has positive and negative implications on the use of the al-darurah concept on 
deferred products in order to give due consideration to the law based on current factors. For example, if the product is not supported by figh law then it is proper to refer to the wasail and maqasid elements to ensure that the product is in line with the actual meaning of syarak.

In addition, to better understand how the al-maqașid and al-wasail components play their role in satisfying the current and local needs of the product based on hilah, one must first understand the basis for prohibiting riba al-fadll according to Umar Chapra because of its connection with persecution and repression. Umar Chapras statement emphasised that the prohibition of riba al-faḍl was because the relationship (wasilah) and its intentions must be integrated so that all the deferred products do not lead to the prohibition of usury (riba). Hence, two important elements must be considered when ensuring the hiyal permitted by syarak is consistent with the context of the permission, which is not to transgress the maqașid al-shariah and thus, it needs to fulfil two main principles, which is not to contradict the shariah and not to lead to the violation of the law, either civil or shariah. (Chapra, 2008) 
INTERNATIONAL JOURNAL OF ACADEMIC RESEARCH IN BUSINESS AND SOCIAL SCIENCES Vol. 9, No. 6, June, 2019, E-ISSN: 2222-6990 @ 2019 HRMARS

Table 1: Role of Hilah in Deferred Products

\begin{tabular}{|c|c|c|}
\hline Issue & Contruct & Analysis \\
\hline Process & $\begin{array}{l}\text { Temporarily forms the } \\
\text { hilah-based product }\end{array}$ & $\begin{array}{l}\text { To integrate the actual financial value } \\
\text { and Maqașid muamalat Islam }\end{array}$ \\
\hline Agreement (Akad) & To avoid errors (khilaf) & Product Innovation \\
\hline Frame (Sighah) & Syariyyah & Intention to avoid usury (riba) \\
\hline Role of Intentions & $\begin{array}{l}\text { Intention to obtain } \\
\text { credit }\end{array}$ & $\begin{array}{l}\text { Should be based on darurah ușuliyyah } \\
\text { because of the dire need for the } \\
\text { sustenance of life; hence, it is not } \\
\text { encouraged in a continuous form in } \\
\text { order to avoid economic instability. As } \\
\text { for the Shafii sect, there is no problem } \\
\text { concerning the law pertaining to the role } \\
\text { of intentions as long as its tanzim } \\
\text { process does not transgress mabadi } \\
\text { syarak }\end{array}$ \\
\hline Wasail and maqașid & $\begin{array}{l}\text { Hilah could be related } \\
\text { to usury (riba) but } \\
\text { there is a bigger need, } \\
\text { which is to be an } \\
\text { alternative to bank } \\
\text { interest; thus, the } \\
\text { relationship, whereby } \\
\text { hilah is permitted as } \\
\text { long as its aim is } \\
\text { permissible }\end{array}$ & $\begin{array}{l}\text { Need to apply sad al-dzharai, rukhșah } \\
\text { and raful haraj according to the current } \\
\text { ijtihad methodology }\end{array}$ \\
\hline
\end{tabular}

The table above shows the components for each element related to hilah that plays a role in the formation and practice of deferred products in Malaysias Islamic banking sector.

\section{Conclusion}

The classical debate about hiyal should be reviewed because it is difficult to decide whether hilah can overcome difficulties in managing legislation or hilah is used until is causes the loss of meaning of the syarak (Ismail, 2010 ; Vogel \& Hayes, 1998). Hence, the ḍarurah ușuliyyah maqașidiyyah framework is needed to ensure the actual use of hilah in the current context. 
Therefore, the wisdom in interacting with the interpretation of the nas Al-Quran and law ethics is strongly required so that the use of hilah is within the permitted confines and not based on hilah shariyyah. Prohibiting actual usury (riba) is aimed at ensuring justice while rejecting abuse and persecution. The prohibition is clearly aimed at safeguarding justice and avoiding all forms of exploitation through unfair transactions and also back-door or illicit usury ( $r i b a$ ) because according to Shariah, all that leads to the prohibited (haram) is prohibited (haram). (Ibn Rushd, 2006 ; Chapra, 2008)

\section{Corresponding Author}

Sumayyah Abdul Aziz, Faculty of Islamic Contemporary Studies, Universiti Sultan Zainal Abidin, Gong Badak Campus, Kuala Nerus, Terengganu, Malaysia.

\section{References}

Ahmad, M. F., Ismail, M. A. (2011). Pendekatan Baru Pembiayaan Peribadi Satu Cadangan, A New Approach in Personal Financing: A Proposal in Journal Prosiding Perkem 4(2), 178-183.

Ahmed, H. (2011). Maqașid al-Shariah and Islamic Financial products: A framework for assessment. ISRA International Journal of Islamic Finance. 3(1), 149-160.

Ahmed, H. (2011). Defining Ethics in Islamic Finance: Looking Beyond Legality. Paper presented at 8th International Conference on Islamic Economics and Finance, Center for Islamic Economics and Finance. December 18, pp. 1-10.

Ashraf, M. H., Iqbal, I., Hussain, L., Marjan, M., Fairooz, M, Bouheraoua, S. (2015). The Parameters of Hiyal in Islamic Finance. ISRA Research Paper. Kuala Lumpur: International Shariah Research Academy, pp. 25-26.

Ashrof, M. Z. Y., Mahyuddin, M. K. (2014). Hiyal in Islamic Financial Product: An Analysis on alIjarah Based Contract in Malaysia. Paper presented at ACIS Seminar Processdings International Halal Conference (INHAC 2014). Novermber 17, pp. 391-400.

Asyraf, W. (2008). Islamic Finance an Old Skeleton in A Modern Dress. Kuala Lumpur: International Shariah Research Academy for Islamic Finance.

Bakar, A., Musa, M. \& Smolo, E. (2009). Al-Hilah (Legal Trick) and Makhraj (Legal Exit): The Diffrence Between the Two and Their Application in Islamic Finance. Paper presented at International Seminar on Muamalat, Islamic Economics and Finance (SMEKI09), October 20, pp. 690.

Chapra, M. U, (2008). The Islamic Vision of Development in the Light of Maqașid al-Shariah. Working Paper. (pp. 1-52). The International Institute of Islamic Thought.

Chapra, M. U. (2008). The Nature of Riba and its Treatment in the Quran, Hadith and Figh. In (Ed.), An Introduction to Islamic Economic and Finance, (pp. 53). CERT Publication.

Dien, M. I. (2008). Islamic Law: From Historical Foundations to Contemporary Practice. Ediburgh: Edinburgh University Press.

Hatta, M. M., Dien, M. I. \& Mohamad, Saadiah. (2014). Examining the Impact of Islamic Products on Debt Expansion and Inflationary Pressure. International Interdisciplinary Journal of Scientific Research, 1(2), 13-28. 
INTERNATIONAL JOURNAL OF ACADEMIC RESEARCH IN BUSINESS AND SOCIAL SCIENCES Vol. 9, No. 6, June, 2019, E-ISSN: 2222-6990 @ 2019 HRMARS

Hayes, Samuel L., Vogel, Frank E., lii. (1998). Islamic Law and Finance: Religion, Risk, and Return. International Journal of Middle East Studies, 31(4), 345.

Ibn al-Qayyim al-Jawziyyah, M. A. B. (1996). Ilam al-Muwaqqiin. Beirut: Dar al-Kutub alIlmiyyah.

Ibn al-Qayyim al-Jawziyyah, M. A. B. (1996). Ilam al-Muwaqqiin. Vol. 3 .Riyadh Makkah: Maktabah Nazar Mustafa al-Baz.

Ibn al-Qudamah, A. M. A. A. M. (2004). Al-Mughni. Lubnan: Bayt al-Afkar al-Dauliah.

Ibn Batttah, U. M. (1988). Ibtal Hiyal. Beirut: al-Maktab al-Islami.

Ibn Hajar al-'Asqalani, A. A. A. (1999). Fathul al-Bari Syarah Șahih al-Bukhari. Beirut: Dar al-Salam al-Ilmiyah.

Ibn Rushd, M. A. (2006). Bidayah al-Mujtahid Wa Nihayah al-Muqtasid. Vol. 2. Tahqiq: Haitham Jumah Hilal. Beirut: Muassasat al-Ma`arif.

Iqbal, M. (2013). Islamic Finance: Islamic Finance: An Attractive New Way of Financial Intermediation. The International Journal of Banking and Finance, 10(2), 1-24.

Khașșaf, A. B. A. A. (1968). Al- Kitab al-Hiyal wa al-Makharij. In (Ed.), Das Kitab al- hiyal u్xalmaharig. Hildesheim: Georg Olms Verlagsbuchhandlung.

Mahmoud A., \& Elgamal. (2006). Islamic Finance: Law, Economics, and Practice. New York Cambridge University Press. Jornal of King Abdul Aziz University, 21(2), 97-108.

Mahrus, Moh. (2013). Aplikasi al-Dzarîah dan al-Hîlah Perspektif Hukum Islam. Jurnal Hukum Islam, 12(1), 1-21.

Mujam al-Wasit. (1972). Entri: hiyal. (Vol. 1). Second Reprint. Mesir: Maktabah al-Shorouk alDauliyah.

Saleh, N. A. (1991). Unlawful Gain and Legitimate Profit in Islamic Law: Riba, Gharar and Islamic Banking, Reviewed by Hasanuzzaman, S. M. Journal of King Abdul Aziz University: Islamic Economics. 3, 115-124.

Al-Sarakhsi, A. B. M. A. S. (1999). Min al-Kitab al-Mabsuth. Al-Qahirah: Maktabah Thaqafah alDiniyah.

Al-Shatibi, A. I. (2003). Al-Muwafaqat fi Ușul al-Shariah. Al-Qahirah: Maktabah Taufiqiah.

Al-Shaybani, A. M. H. (1999). Al-Makharij fi al-Hiyal. Al-Qahirah: Maktabah al-Thaqafah alDiniyah.

Sumayyah A. A. (2016). Kedudukan Akad-Akad Bertangguh di Institusi Perbankan Islam Menurut Maqasid al-Shariah. In (Ed.), Maqasid al-Shariah: Aplikasi dalam Aspek Muamalat dan Kehartaan (pp. 247). Universiti Malaya.

Udovitch, A. (1981). Bankers Without Banks: Commerce, Banking and Society in The Islamic World of the Middle Ages. Princeton: Princeton University.

Ibn Qayyim al-Jawziyyah, Muhammad ibn Abi Bakar, Ilam al-Muwaqqiin(Beirut: Dar al-Kutub alIlmiyyah, 1

Ibn Qayyim al-Jawziyyah, Muhammad ibn Abi Bakar, Ilam al-Muwaqqiin(Beirut: Dar al-Kutub alIlmiyyah, 19 